TITLE: Adding Insult to Injury: Consumer Experiences of Being Denied Credit

SHORT TITLE: Being Denied Credit

AUTHORS: Charlene Jennett, Sacha Brostoff, Miguel Malheiros and M. Angela Sasse

AFFILIATION: Computer Science Dept., University College London, UK

CORRESPONDING AUTHOR: Charlene Jennett

ADDRESS: University College London, Computer Science Dept., Malet Place Engineering

Building, Gower Street, London WC1E 6BT

EMAIL: c.jennett@cs.ucl.ac.uk 


\title{
Adding Insult to Injury: Consumer Experiences of Being Denied Credit
}

\begin{abstract}
To inspire confidence in consumer credit and improve outcomes for consumers, negative experiences such as being denied credit must be handled appropriately. We conducted an online survey with 298 UK citizens who had a credit application denied to gain a better understanding of their experience of being denied credit. We found that privacy issues make this experience more upsetting for consumers than necessary. When being denied credit, respondents are most concerned about (1) being denied credit 'in public', and (2) not being informed about the reasons why they are denied. Only 23\% of our respondents knew why they had been denied; 116 (62\%) believed they had been denied credit because of their credit record, but 28\% had never checked it. Out of the 194 respondents who had checked their record, 38 identified errors in their credit reports, and in 14 of these cases (38\%) debts that they had paid off were incorrectly listed as outstanding. Based on our findings, we propose several changes to the credit application process: (1) providing sensitive but helpful information in a private manner, e.g. a preview of their credit score before they commit a loan application, (2) credit denial notifications with information on what to do next, and (3) giving applicants more information about checking their credit report and who to contact for correcting errors.
\end{abstract}

Keywords: privacy, consumers, credit, finance, education, technology 


\section{INTRODUCTION}

There has been massive growth in consumer credit lending over the last 30 years driven by revolving credit and the increasing use of computer technology (Griffiths, 2008). Access to credit can improve consumers' circumstances - it may enable them to buy a car to travel to work, buy their own home, start their own business, or cope with emergencies. There can be status associated with having access to credit - for example, having a store card can make cardholders feel “special” and can provide them with greater financial confidence (Erasmus \& Lebani, 2008; Wickramasinghe \& Gurugamarge, 2012). However, applying for credit does not always lead to a positive outcome. In this paper we focus on the consumer experience of being denied credit. We describe findings from our survey study which suggest that whilst it is an inherently negative experience, privacy issues make this experience more upsetting for consumers than it needs to be. Drawing on our human-computer interaction (HCI) knowledge, we then propose several online solutions that could potentially help to inspire confidence in consumer credit and improve outcomes for consumers.

\section{Background}

Technology has dramatically increased the speed at which lending decisions can be made instead of having to wait several days, lending decisions are now available instantly. With the move to online applications and widespread access to the Internet, the convenience of loan applications for consumers has increased significantly. Computer technology has also made the risk assessment at the centre of lending decisions substantially more accurate (Hand et al., 2008). The statistical decision making applied to the datasets collected and made available by Credit Reference Agencies (CRAs) has dramatically reduced costs to loan providers (Avery et al., 2004) so they can offer loans to more consumers with greater confidence that they will 
be repaid. And because loan providers have to write off fewer bad debts, they can offer loans at better conditions, which potentially means widening access.

The survival of a loan provider depends on its ability a) to collect and process information about loan applicants, and b) to monitor the repayment performance of any loan applicants they accept and promote to the status of "borrowers" (Jappelli \& Pagano, 2000). Sharing information with other parties - such as CRAs - is part of this process. Applying a statistical modelling technique known as credit scoring, loan providers use CRA data along with other information they hold to decide which applicants to lend to - and who not to lend to.

\section{Privacy and Lending}

While there are clear incentives for loan providers to share loan applicants’ and borrowers’ information (in fact they are contractually obliged to share these with CRAs if they themselves make use of CRA data), applicants might not feel as positive about their information being shared with third parties. Adams and Sasse (2001) identify factors that affect users' perceptions of the sensitivity of electronic data items in their privacy model. Many instances of loan applications occur online, so we believe that the Adams and Sasse (2001) model is applicable: the loan applicant takes on the role of the system user, transmitting their data to the loan provider. They identify two factors that contribute to the sensitivity of data. Firstly, the consumer's perception of the privacy implications of a disclosure depends on their level of trust in the information receiver - which is determined by past experience, reputation and the type of relationship they have. Secondly, the consumer's expectation of the information usage - i.e. the purpose for which information is used.

An invasion of privacy occurs when the consumer realises that the risks associated with the disclosure of a data item exceed the benefits of it having been disclosed. When a consumer 
finds that data items they believe to be positive or innocuous are unexpectedly used against them, the result is an emotive response, leading to a rejection of the system or process that disclosed the data item, and decreased trust in the organisation that owns the system or process. In the domain of online financial services, this might result in harm to the loan provider's brand once applicants start to distrust a loan provider.

It has previously been demonstrated that Adams and Sasse’s privacy model (2001) can be applied to lending contexts. Jennett et al. (2011) reported the results of three studies with loan applicants and identified three privacy issues when completing credit card application forms: a) perceived relevance of information provided, b) expected usage of information, and c) perceived accuracy and fairness of the application process. They found that loan applicants had incorrect perceptions of how information from their loan applications would be used by loan providers, and perceived loan providers as “unfair”, e.g. because they did not take their full circumstances into account. Some applicants reported not continuing with the application process because of fear of rejection - because they did not want to disclose information that would show them in a negative light, or to avoid the embarrassment of being rejected. Some of these applicants might have been viable applicants, i.e. a lost customer for the loan provider.

\section{Privacy and Being Denied Credit}

In this paper, we focus on privacy perceptions in the context of credit applications being denied. There are several indications that privacy could be an issue in this context. Firstly, past research suggests that financial literacy is low. In a survey of 1,000 US residents, only one third understood the workings of credit and $11 \%$ were unable to assess their debt position (Lusardi \& Tufano, 2009). In another study, a strong relationship was found between overly pessimistic self-assessments of credit scores, being denied credit and experiencing a "bad" 
financial event (Courchane et al., 2008). These findings suggest that there exists a mismatch in applicants' perceptions of the information usage and the reality of it when the negative event - credit denial - occurs.

Secondly, loan providers give minimal information as to why the applicant is denied credit in order to prevent gaming of the risk assessment process. In some cases, it is only when the applicant asks “why?” that the loan provider will give them an explanation. This lack of information makes it possible that misunderstandings will occur as applicants second-guess why they have been denied credit.

Thirdly, CRA data is not always accurate. "Serious errors" are those that have a high probability of the applicant being incorrectly denied credit; these include: (1) accounts incorrectly marked as delinquent or defaulted, or (2) credit reports containing data - credit accounts, public records, or judgments - that do not belong to the consumer (Jentsch, 2010). If an applicant is unaware that there are errors on his account, then again there will be a mismatch of perceptions of information usage when she applies for credit and finds herself denied.

\section{Research Questions}

To gain a better understanding of loan applicants' experiences of being denied credit and the underlying privacy issues that could be involved, we decided to conduct an online survey study. We aimed to explore the following questions:

1. What are loan applicants' experiences of being denied credit? Do they know why they were denied?

2. Did the loan applicants check their credit record? And if so, did they discover inaccuracies? 


\section{METHODOLOGY}

\section{Sample}

UK respondents were recruited according to a nationally representative sampling frame via the market research company e-Rewards. ${ }^{1}$ Experience of being denied credit was a prerequisite for participation. 320 survey responses were collected in total; however 78 were excluded due to missing or irrelevant responses in the open-text questions (e.g. typing in “n/a” or random letters). Therefore the analysis is based on 298 respondents only.

The characteristics of the sample are summarised in Tables 1, 2 and 3. There was a larger representation of females (67.8\%), the age category “24-39 years” (49\%), employment status category “full-time employment” (53\%), and current financial circumstances category “manageable debt” (56.4\%).

Table 1. Gender and age of respondents $(N=298)$

\begin{tabular}{|c|c|c|c|c|c|c|c|c|c|c|c|c|c|c|c|}
\hline \multicolumn{6}{|c|}{ Gender } & \multicolumn{10}{|c|}{ Age (years) } \\
\hline \multicolumn{2}{|c|}{ Male } & \multicolumn{2}{|c|}{ Female } & \multicolumn{2}{|c|}{ Total } & \multicolumn{2}{|c|}{$18-24$} & \multicolumn{2}{|c|}{$25-39$} & \multicolumn{2}{|c|}{$40-59$} & \multicolumn{2}{|c|}{$60+$} & \multicolumn{2}{|c|}{ Total } \\
\hline$n$ & $\%$ & $n$ & $\%$ & $\bar{N}$ & $\%$ & $\bar{n}$ & $\%$ & $n$ & $\%$ & $n$ & $\%$ & $\bar{n}$ & $\%$ & $\bar{N}$ & $\%$ \\
\hline 96 & 32.2 & 202 & 67.8 & 298 & 100 & 37 & 12.4 & 146 & 49.0 & 102 & 34.2 & 13 & 4.4 & 298 & 100 \\
\hline
\end{tabular}

Table 2. Employment status of respondents $(N=298)$

\begin{tabular}{|c|c|c|c|c|c|c|c|c|c|c|c|c|c|c|c|c|c|}
\hline \multicolumn{18}{|c|}{ Employment Status } \\
\hline \multicolumn{2}{|c|}{$\begin{array}{l}\text { Full-time } \\
\text { employ- } \\
\text { ment }\end{array}$} & \multicolumn{2}{|c|}{$\begin{array}{l}\text { Self- } \\
\text { employ- } \\
\text { ment }\end{array}$} & \multicolumn{2}{|c|}{$\begin{array}{l}\text { Part-time } \\
\text { employ- } \\
\text { ment }\end{array}$} & \multicolumn{2}{|c|}{$\begin{array}{l}\text { Temporary } \\
\text { employ- } \\
\text { ment }\end{array}$} & \multicolumn{2}{|c|}{ Retired } & \multicolumn{2}{|c|}{ Student } & \multicolumn{2}{|c|}{$\begin{array}{l}\text { Looking } \\
\text { after } \\
\text { family / } \\
\text { home }\end{array}$} & \multicolumn{2}{|c|}{$\begin{array}{l}\text { Permanently } \\
\text { sick / } \\
\text { disabled } \\
\end{array}$} & \multicolumn{2}{|c|}{ Total* } \\
\hline$n$ & $\%$ & $n$ & $\%$ & $n$ & $\%$ & $n$ & $\%$ & $n$ & $\%$ & $n$ & $\%$ & $n$ & $\%$ & $n$ & $\%$ & $N$ & $\%$ \\
\hline 158 & 53.0 & 17 & 5.7 & 52 & 17.4 & 4 & 1.3 & 9 & 3.0 & 12 & 4.0 & 30 & 10.1 & 14 & 4.7 & 298 & 100 \\
\hline
\end{tabular}

\footnotetext{
${ }^{1}$ subsequently re-branded as Research Now, http://www.researchnow.com/
} 
Table 3. Current financial circumstances of respondents $(N=298)$

\begin{tabular}{|c|c|c|c|c|c|c|c|c|c|c|c|}
\hline \multicolumn{12}{|c|}{ Current financial circumstances } \\
\hline \multicolumn{2}{|c|}{ Debt free } & \multicolumn{2}{|c|}{$\begin{array}{l}\text { Manageable } \\
\text { debt }\end{array}$} & \multicolumn{2}{|c|}{ Problem debt } & \multicolumn{2}{|c|}{$\begin{array}{l}\text { Individual } \\
\text { Voluntary } \\
\text { Agreement }\end{array}$} & \multicolumn{2}{|c|}{ Bankrupt } & \multicolumn{2}{|c|}{ Total } \\
\hline$n$ & $\%$ & $n$ & $\%$ & $n$ & $\%$ & $n$ & $\%$ & $n$ & $\%$ & $N$ & $\%$ \\
\hline 52 & 17.4 & 168 & 56.4 & 60 & 20.1 & 13 & 4.4 & 5 & 1.7 & 298 & 100 \\
\hline
\end{tabular}

\section{Survey}

A 34-item online survey was created using the open source software Limesurvey. ${ }^{2}$ The survey took approximately 15 minutes to fill in and respondents were rewarded by e-Rewards for their participation. The survey included a mixture of close-ended and open-ended questions and consisted of the following components:

- Demographics and Current Financial Circumstances. Respondents selected their age bracket, gender, employment status and current debt situation.

- Experience of Credit Denial. Respondents were asked which sources of credit they had been denied and to write about their experience - i.e. why were you denied? How did being denied make you feel?

- Knowledge of Credit Record. Respondents were asked when did the last check their credit record, which CRA did they use to check their credit record, and if they were surprised by the knowledge the CRA had about their financial circumstances. Respondents were also asked about the credit record itself: did they feel their credit record reflected their current financial situation accurately; could they remember any incidents where their credit record was inaccurate, and if so, how easy or difficult was it to correct the record.

\footnotetext{
${ }^{2}$ http://www.limesurvey.org/
} 
- Information Sources Used. Respondents were asked what information source(s) they would go to for advice about obtaining credit.

\section{Data Analysis}

To describe the basic body of the data we calculated descriptive statistics (frequencies). To analyse responses to the open-ended questions we used thematic analysis - a qualitative method for identifying, analysing and reporting patterns (themes) within data (see Braun and Clarke, 2006, for more information about thematic analysis).

\section{RESULTS}

\section{Experience of Being Denied Credit}

All 298 respondents had experience of being denied credit. The types of credit respondents had been denied are summarised in Table 4. Most respondents had experienced being denied bank credit cards (54\%), bank loans (36\%), bank overdrafts (35\%) and catalogues (27\%). For those that selected "other" (21\%), the open text responses included other types of credit card (e.g. supermarket credit) and mobile phone contracts.

Table 4. Types of credit respondents were denied $(N=298)$

\begin{tabular}{|c|c|c|c|c|c|c|c|c|c|c|c|c|c|c|c|c|c|c|c|}
\hline \multicolumn{20}{|c|}{ Types of credit denied } \\
\hline \multicolumn{2}{|c|}{$\begin{array}{l}\text { Bank } \\
\text { overdraft }\end{array}$} & \multicolumn{2}{|c|}{$\begin{array}{l}\text { Bank } \\
\text { loan }\end{array}$} & \multicolumn{2}{|c|}{$\begin{array}{l}\text { Bank } \\
\text { credit } \\
\text { card } \\
\end{array}$} & \multicolumn{2}{|c|}{$\begin{array}{l}\text { Bank } \\
\text { credit } \\
\text { extension }\end{array}$} & \multicolumn{2}{|c|}{$\begin{array}{l}\text { Cat- } \\
\text { alogue }\end{array}$} & \multicolumn{2}{|c|}{$\begin{array}{l}\text { Store } \\
\text { card }\end{array}$} & \multicolumn{2}{|c|}{$\begin{array}{l}\text { Credit } \\
\text { Union }\end{array}$} & \multicolumn{2}{|c|}{$\begin{array}{l}\text { Doorstep } \\
\text { lender }\end{array}$} & \multicolumn{2}{|c|}{ Other } & \multicolumn{2}{|c|}{ Total* } \\
\hline$n$ & $\%$ & $n$ & $\%$ & $n$ & $\%$ & $n$ & $\%$ & $n$ & $\%$ & $n$ & $\%$ & $n$ & $\%$ & $n$ & $\%$ & $n$ & $\%$ & $N$ & $\%$ \\
\hline 103 & 35 & 108 & 36 & 161 & 54 & 68 & 23 & 80 & 27 & 39 & 13 & 3 & 1 & 3 & 1 & 62 & 21 & 298 & 100 \\
\hline
\end{tabular}


Out of the 298 respondents, 204 provided details about their experiences of being denied credit and how it made them feel using the open text box. Out of these, 186 respondents mentioned whether they were given a reason for why they were denied credit. As can be seen in Figure 1, 116 were denied because of their credit record (62\%), 27 were denied for another reason (15\%), and 43 did not know why they were denied (23\%).

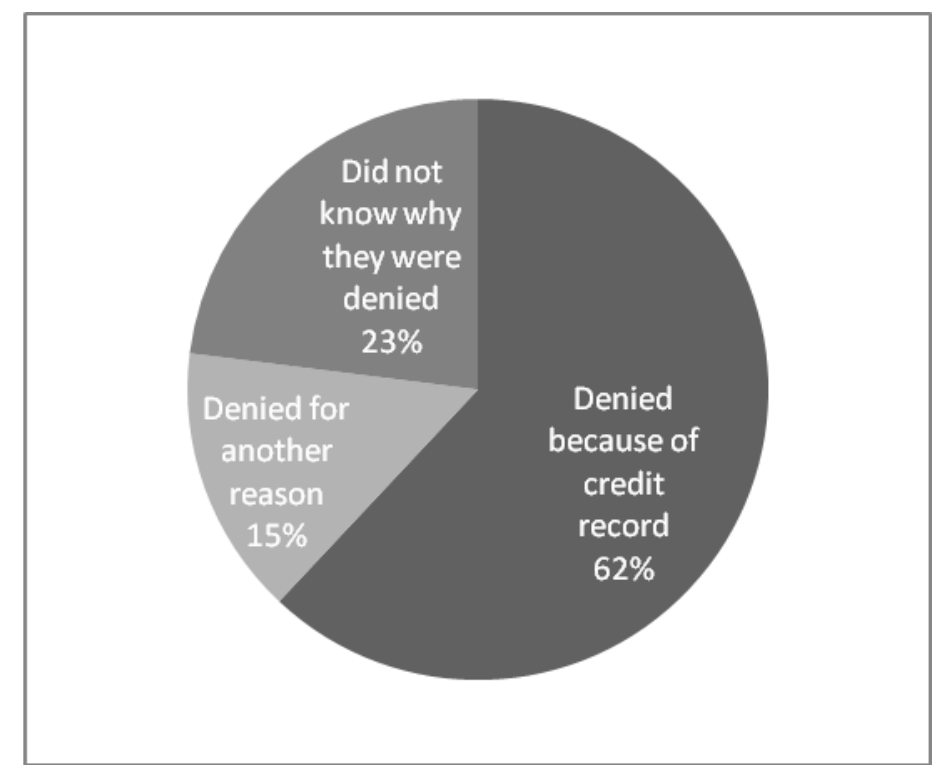

Figure 1. A pie chart showing percentages of the reasons respondents gave for why they were denied credit $(N=186)$

Respondents tended to use emotive words such as "frustrated”, “embarrassed”, “angry”, “depressed”, “poor”, “rejected”, “unworthy”, and "second class”, to describe their experiences. Some felt that the denial was unjust. E.g. P172: “Went to the bank for a short extension of my overdraft, just for one month, and was denied due to a poor credit scoring. Felt embarrassed and let down. I thought banks were supposed to help [...] obviously not. Only the rich get help."

Respondents who had applied for a bank loan with a bank that they had been with for many years felt particularly annoyed, feeling that the situation should have been dealt with better. 
They felt that there was no sense of loyalty to the customer. E.g. P219: "I asked for a loan to pay off my credit card [...] from a bank I had been a loyal customer for many years, as well as my family. I felt embarrassed, and sense of no customer loyalty towards me. Instead I went to a supermarket and got a loan from them."

Those that were denied due to having no credit rating, as opposed to a poor credit rating, also felt frustrated. They felt that they were in a "catch 22" situation - unable to get credit because they had no credit. E.g. P262: “I had no credit rating because I have no debt and it made me feel angry that I cannot get credit because I do not have debt. If I had debt, presumably it would be no problem to get more debt!"

As shown in Figure 1, 23\% of respondents said that they did not know why they had been denied. This further compounded their feelings of frustration and embarrassment. Being denied in public spaces was also an issue. E.g. P33: "I tried to get a store card, I do not know why I was denied it. I was embarrassed because a large queue had formed behind me and people were tutting and getting impatient."

The experience of being turned down also made some respondents fearful of applying for future credit. E.g. P55: "I was refused credit for a store card. They did a credit check I assume my credit score was bad. I felt ashamed and embarrassed and it has made me fearful of applying for future credit."

\section{Knowledge of Credit Record}

As can be seen in Figure 2, $(N=298) 61$ respondents (20\%) said that they had checked their credit record within the last 6 months, 36 within the last year (12\%), 33 over a year ago (11\%), 38 over 2 years ago (13\%), 20 over 5 years ago (7\%), and 6 over 10 years ago (2\%). 104 had never checked their credit record (35\%). 


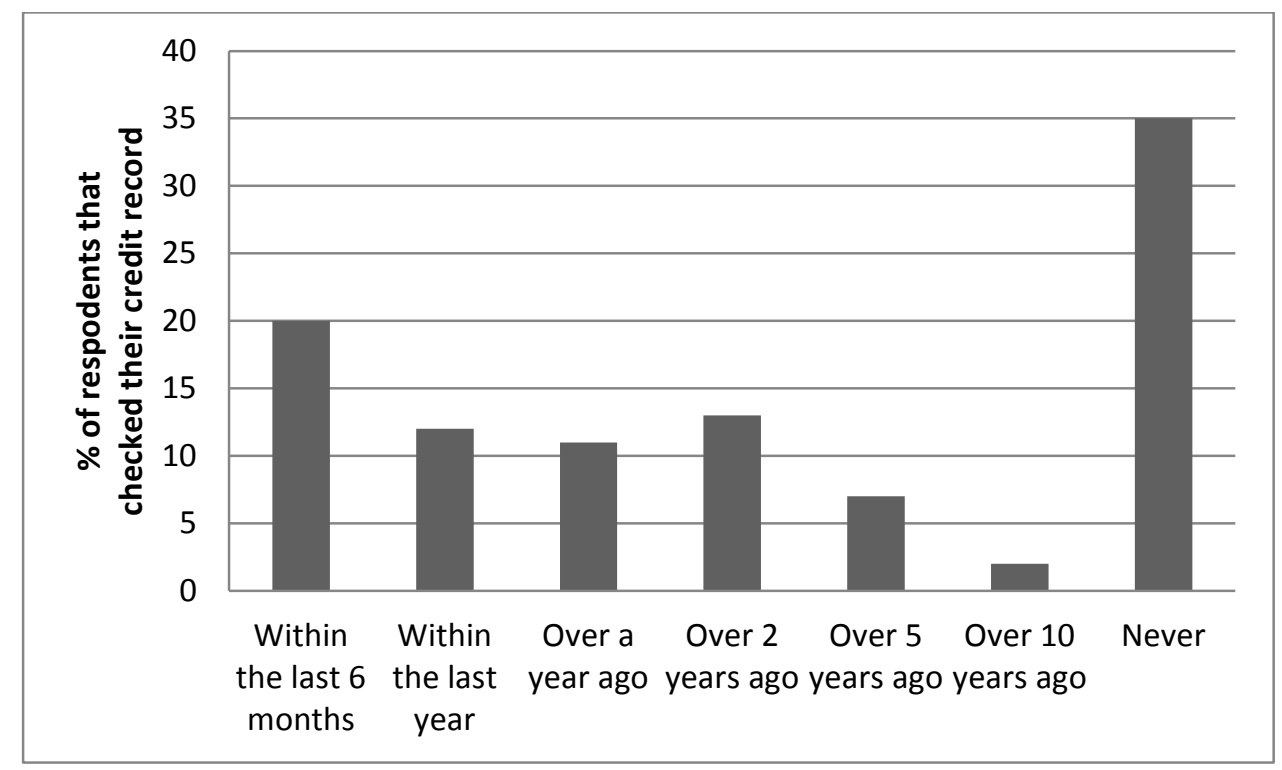

Figure 2. A bar chart showing percentages of when respondents last checked their credit record $(N=298)$

For those that had checked their credit record $(N=194), 157$ reported that they had used Experian (81\%), 28 used Equifax (9\%), 6 used CallCredit (2\%), and 3 selected “other” (1\% their open text responses were “online”, “not sure, was checked by bank”, “don’t know”).

Fourteen respondents $(7 \%, N=194)$ were surprised at the amount of information that credit rating companies had on record. E.g. P203: "Experian, I paid £2.00 and got a full rundown of almost everything I had on terms, loans and other things, OH Electric and Gas Company as I was in arrears but had already started a repayment plan some 6 months previous. THEY KNEW ALMOST ALL MY FINANCIAL HISTORY, this is a private company, NOT my bank, so why are they allowed to hold this information?”

Asked whether they felt their credit record accurately reflected their current financial situation, ( $N=298) 118$ selected “yes” (40\%), 44 selected “no” (15\%), and 136 selected “don’t know” (46\%). Out of those who had checked their credit record (194), 58 (30\%) didn’t know if it reflected their financial situation accurately, and 31 (16\%) said that it did not. Of the respondents who had never checked their credit record, 78 (75\%) did not know if it 
accurately reflected their financial situation, but 13 respondents (12.5\%) believed it did, and a further 13 believed it did not.

Thirty-eight respondents $(13 \%, N=298)$ said that they had experienced incidents where their credit record was inaccurate - 19\% of the 194 who had checked their record. Out of these, 36 gave clear responses of what the incident was. The inaccuracies related to debt included: outstanding debt that had been paid off (14 respondents - 38\%); outstanding debt despite bankruptcy (2 respondents $-6 \%)$; incorrect debt (1 respondent - 3\%). One respondent said that the inaccuracy they encountered was debts not showing up on their record - and perhaps not surprisingly, the respondent chose not to correct this.

There were inaccuracies related to incorrect information: association with ex-partner still in the account after divorce / break up (3 respondents); incorrect electoral roll information (3 respondents); incorrect alias on account (3 respondents); confused with relative (2 respondents); incorrect address (3 respondents); name change after getting married (1 respondent); unauthorised credit checks (1 respondent). There were also inaccuracies due to fraud: 2 respondents described incidents where somebody had used their credit card details and the accumulated debt affected their credit record.

When asked how easy they found it to correct inaccuracies on their credit records, 23 respondents gave clear answers. Out of the 23, 8 respondents (35\% of those that found an inaccuracy) found the inaccuracy easy to resolve. E.g. P229: "Still showed old debts that I had paid off, I sent a letter, problem was fixed straight away.” Thirteen respondents (57\%) found the inaccuracy was difficult to resolve, describing the process as "time consuming" and there being “no clear guidance”. E.g. P98: “I have a debt to a mobile phone I wasn't aware of and I'm not entirely sure it's my debt. It's from years ago. So when I say I am debt free, I still have this outstanding debt on my credit record. I haven't sorted it out yet as there is no 
guidance on how to do so other than contacting the company directly and this is very difficult as they don't appear to have a head office."

Two respondents (9\%) reported that the problem was resolved once they contacted a CRA and asked them to get involved. E.g. P254: “Debt (interest free / repayment free period on purchase) was represented incorrectly - contacted the company involved who ignored me so I contacted Experian who were very helpful and contacted the company and had the matter resolved - OK to resolve once Experian got involved."

\section{Information Sources Used}

As can be seen in Figure 3, the top 5 information sources respondents would go to for advice about credit were Internet social networking sites (15\%), bank / other loan providers (12\%), shopkeepers (11\%), and internet discussion groups (10\%). Respondents were least likely to ask their close friends (2\%) and parents (2\%). 


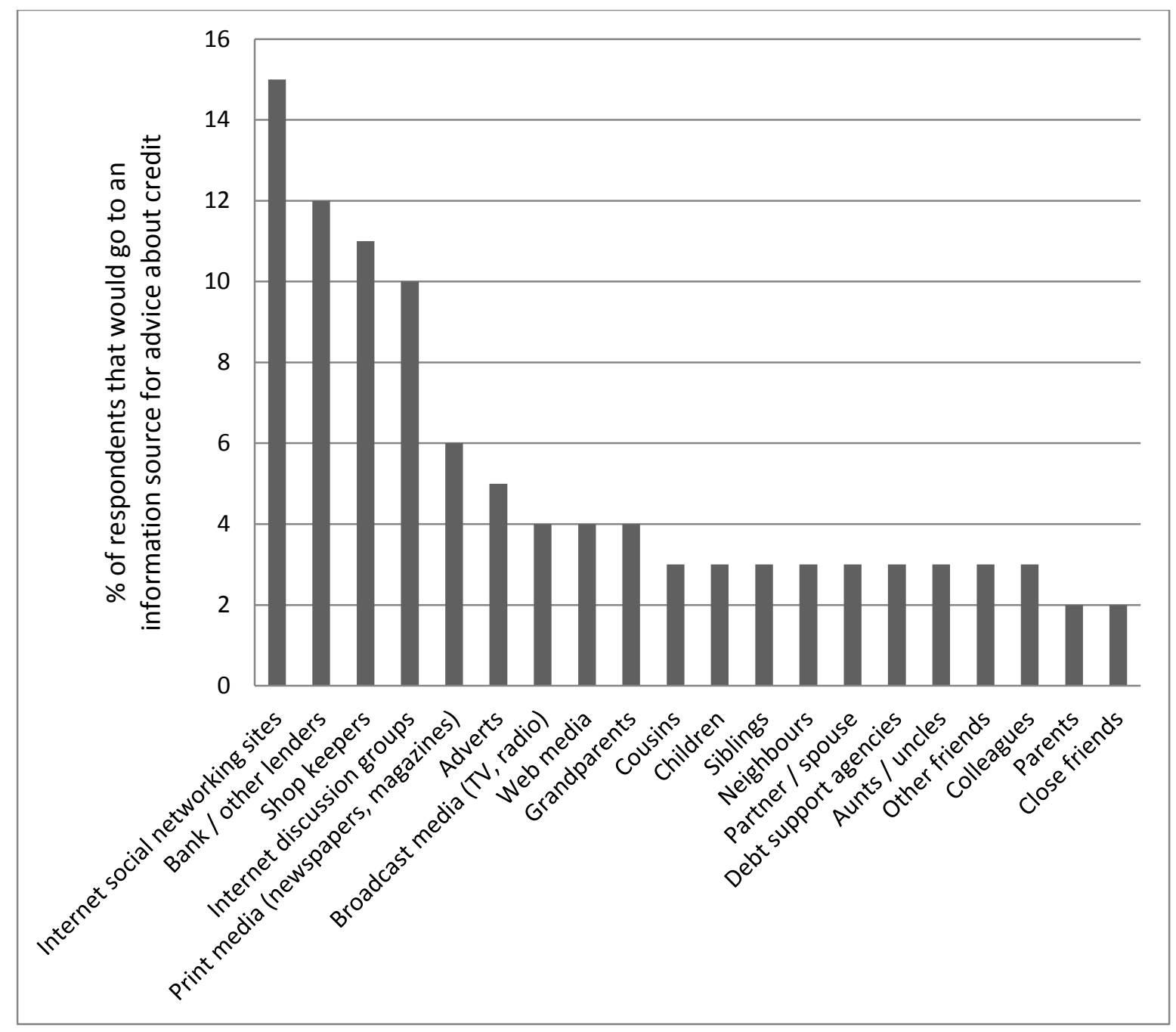

Figure 3. A bar chart showing percentages of respondents that would go to an information source for advice about credit $(N=298)$

\section{DISCUSSION}

\section{Experience of Being Denied Credit}

The aim of our research was to explore privacy issues in the context of credit denial. There were two key findings. Firstly, respondents found being denied credit in stores particularly embarrassing. This indicates that public places are a context in which there is high information sensitivity - making the potential for a privacy invasion more likely. Secondly, $23 \%$ of respondents did not know why they were denied credit. In line with Adams and Sasse 
(2001), we suggest that this lack of knowledge leads to a mismatch between the user's perceptions of information usage and the reality of the situation (invasion of privacy). As a result, respondents described feeling frustrated (emotive response), no sense of customer loyalty (decreased trust in the information receiver) and were fearful of applying for future credit (rejection of the system). These findings also illustrate that customers still have a relationship model of banking in mind - wanting to be seen and treated as individuals whereas the bank's actions are made in line with transaction rules.

To overcome these privacy issues and help customers feel more valued, we suggest that applicants should be informed of why they have been denied credit without having to ask. The use of an automated system for dissemination would increase the likelihood that this information would reach applicants. It would also ensure consistent quality of information, whereas previously the quality supplied by loan providers could vary substantially between branches and tillers within branches (Datta, 2009).

We also suggest that there needs to be a more private method of informing the applicant that he/she has been denied credit. The applicant could receive a credit rejection through a text message or some other form of written communication, rather than it being said out loud by the person at the till. This would make the experience less embarrassing for the recipient, as the information would be less likely to leak to people physically close by. Encryption technology could be used to further cloak the contents of the message - so that, for example, applicants’ mobile phone networks would not be able to read the messages.

\section{Knowledge of Credit Records and Inaccuracies}

Another aim of our research was to explore whether loan applicants who had been denied credit had ever checked their credit record. The survey results revealed that $35 \%$ of 
respondents had never checked their credit record; $46 \%$ did not know whether their credit record reflected their current financial situation accurately; and out of those that had checked their credit record, 7\% were surprised at the amount of information the CRAs have in their records. Again these findings suggest that consumers do not understand transaction banking in particular, the role of credit scores. This supports previous research findings, which suggest that consumers lack knowledge about the workings of credit and credit scores (Lusardi \& Tufano, 2009; Courchane et al., 2008). This lack of knowledge explains why applicants do not understand why they are denied credit.

We also asked respondents whether they had ever experienced inaccuracies in their credit records. Out of the 194 respondents that had checked their credit record, 19\% had identified errors. Furthermore, 38\% of these errors were debts that had been paid off being listed as outstanding. These would be regarded as serious errors, as they could possibly result in the applicant being denied credit (Jentsch, 2010). It is also possible that a proportion of the 104 respondents who had never checked their credit record have inaccuracies and do not realise it. Obviously, it is also in the CRAs' and loan providers' interest that records are accurate, so every effort should be more to encourage consumers in general - and prospective loan applicants in particular - to check their credit record and report inaccuracies. There needs to be more guidance on how to report an inaccuracy and request a correction: our findings show that $57 \%$ of respondents who reported an inaccuracy found it difficult to resolve.

To overcome these issues, we suggest that applicants need to be educated about credit records. It also needs to be made easier for applicants to check their credit records. For example, it could be useful to give loan applicants a preview of their credit score at an early state of the application. A preview of their credit score would allow applicants to gauge the chances of their application being accepted or rejected, and an opportunity to check and 
correct the personal data in their credit record. Also when inaccuracies are found on credit records, it needs to be made clear whether the person should contact the original company or the CRA to correct the mistake. One of the UK CRAs is already in the process of lowering the barriers for individuals to access their credit records, by offering a free online service. Similarly, Jentsch (2003) writes "one of the worst mistakes is to cut out the consumer by making it difficult for him/her to access the report or making it costly.”

Another solution could involve making use of "teachable moments." Being denied credit is an ideal "teachable moment" in which consumers will be more receptive to financial education. When notified of the rejection, the recipient should be told which CRA was used and encouraged to check their credit record for inaccuracies. By checking their credit record, the applicant can verify the information that is being used for credit scoring is correct - which is also a benefit for the loan provider, as correct data means more accurate credit scoring. The recipient should also be given advice of how to get their credit record back on track. Especially if it is the case that applying for further credit could lead to their credit rating getting worse (commonly known as "the rejection spiral”), the applicant needs to be aware of this. An advice leaflet could be enclosed with each rejection notification, or alternatively a link to a reputable advice website. We suggest that this would make the experience of being denied credit less negative - as now the applicant has an idea of what to do next after being refused credit.

One might argue that applicants will be more likely to "game" the system if they know why they are denied credit, however we suggest the opposite - giving applicants more information could be beneficial for loan providers. By checking their credit record the applicant can verify the information that is being used for credit scoring is correct - which is also a benefit for the loan provider, as correct data means more accurate scoring. Also, if an applicant has 
more understanding of their credit status, they might not waste their time applying for credit when they know they stand little chance of getting it - which saves the loan provider time and having to refuse service to potential customers.

There is also a need for greater financial education in general. We suggest that exclusion of people from the use of their own credit records and credit scores through ignorance should be combated with a greater use of socially focused internet resources by parties that support financial literacy - as internet social networking sites and internet discussion groups were two of the most used information sources for our sample. Furthermore, technology can be used to educate consumers in a way that is engaging as well as informative. Possible channels include social networking sites, online games and mobile phone apps.

Finally, we propose that financial education should target children as well as adults. Previous research suggests that money-management teaching in childhood affects future behaviour (Grimstein-Weiss et al., 2010). As children are increasingly using and learning through digital media (see Do-Be $\operatorname{Ltd}^{3}$ ), we suggest that technology could be an ideal medium to teach them about financial management. For example, Channel 4 is currently creating a financial literacy game aimed at children / young adults. ${ }^{4}$

\section{CONCLUSIONS AND RECOMMENDATIONS}

Our research contributes to the consumer credit literature by giving an insight into the perspective and experiences of loan applicants that have been denied credit, a research area that is often understudied. By using a mixture of open-ended and close-ended questions in our survey, we were able to collect rich data about loan applicants’ experiences as well as

\footnotetext{
${ }^{3}$ http://www.do-be.co.uk/

4 "Channel 4 commisions 10 indie game for 2011”, Wired.co.uk, http://www.wired.co.uk/news/archive/201011/10/channel-4-uk-games
} 
quantitative data. Transaction banking has become a necessary development for loan providers to be able to deal with the high volumes of customers; however it is evident that consumers’ mental models have not caught up and they still have a relationship banking model in mind. Privacy invasions - such as being denied credit "in public" or not being given an explanation for credit denial - contribute to issues such as decreased trust in loan providers and avoidance of future lending. We argue that, consequently, the experience of being denied credit is more negative than it necessarily has to be. Instead of pretending in their marketing that they treat customers as individuals, loan providers need to be honest and tell customers what they need to do in order to survive transaction banking.

We have proposed several recommendations to overcome these problems, the majority of which have involved using technology to give applicants more information about their credit status. These recommendations include: (1) providing sensitive but helpful information in a private manner, e.g. a preview of their credit score before they commit a loan application, (2) credit denial notifications with information on what to do next, and (3) giving consumers more information about checking their credit report and how to go about correcting errors.

Future research will be needed to test the feasibility of our recommendations. Also it would be interesting to investigate the relative effect of privacy concerns vs. financial expertise in the types of sources of financial information people use, and whether the privacy issues reported here generalise to other populations outside of the UK.

\section{ACKNOWLEDGMENTS}

This research was conducted as part of Privacy Value Networks (PVNets), an EPSRC grant funded research project. 


\section{REFERENCES}

Adams, A. \& Sasse, M. A. (2001). Privacy in multimedia communication: Protecting users, not just data. In A. Blandford, J. Vanderdonckt \& P. Gray (Eds.), People and Computers XV - Interaction without frontiers: Joint proceedings of HCI 2001 and IHM 2001, 49-64. London: Springer.

Avery, R. B., Calem, P. S. \& Canner, G. B. (2004). Credit Information Reporting and the Practical Implications of Inaccurate or Missing Information in Underwriting Decisions. Joint Center for Housing Studies.

Braun, V. \& Clarke, V. (2006). Using thematic analysis in psychology. Qualitative Research in Psychology, 3, 77-101. doi: 10.1191/1478088706qp063oa

Courchane, M., Gailey, A. \& Zorn, P. (2008). Consumer credit literacy: What price perception?” Journal of Economics and Business, 60 (1-2), 125-138.

doi:10.1016/j.jeconbus.2007.08.003

Culnan, M. J. (1993). How Did They Get My Name?: An Exploratory Investigation of Consumer Attitudes toward Secondary Information Use. MIS Quarterly, 17 (3), 341-363. http://www.jstor.org/stable/249775

Datta, K. (2009). Risky Migrants?: Low-Paid Migrant Workers Coping With Financial Exclusion in London. European Urban and Regional Studies, 16(4). doi: $10.1177 / 0969776409340865$

Erasmus, A. C. \& Lebani, K. (2008). Store cards: Is it a matter of convenience or is the facility used to sustain lavish consumption? International Journal of Consumer Studies, 32 (3), 211-221. doi:10.1111/j.1470-6431.2008.00667.x 
Griffiths, M. (2008). Guest editorial: Themed issue: Consumer issues in credit and debt. International Journal of Consumer Studies, 32 (3), 187. doi:10.1111/j.14706431.2008.00670.x

Grimstein-Weiss, M., Spader, J., Yeo, Y. H., Taylor, A. \& Freeze, E. B. (2010). Parental transfer of financial knowledge and later credit outcomes among low- and moderate-income homeowners. Children and Youth Services Review, 33 (1), 78-85.

doi:10.1016/j.childyouth.2010.08.015

Hand, D. J., Brentnall, A. R. \& Crowder, M. J. (2008). Credit scoring: a future beyond empirical models. Journal of Financial Transformation, 23, 121-128.

Jappelli, Y. \& Pagano, M. (2000). Information Sharing in Credit Markets: A Survey. CSEF Working Paper No. 36, Centre for Studies in Economics and Finance, University of Naples, Italy. Available at http://ideas.repec.org/p/sef/csefwp/36.html

Jennett, C., Malheiros, M., Brostoff, S. \& Sasse, M. A. (2011). Privacy for applicants versus loan providers' needs for predictive power: Is it possible to bridge the gap? In Proceedings of the $4^{\text {th }}$ International Conference on Computers, Privacy \& Data Protection (CPDP 2011), 25-27 January 2011, Brussels, Belgium.

Jentzsch, N. (2010). Financial privacy: An international comparison of credit reporting systems (Second Edition), pp.230-247. Springer-Verlag: Heidelberg.

Lusardi, A. \& Tufano, P. (2009). Debt literacy, financial experiences, and overindebtedness. NBER Working Paper Series, Vol. w14808, 2009. Available at SSRN:

http://ssrn.com/abstract $=1366208$ 
Wickramasinghe, V. \& Gurugamage, A. (2012). Effects of social demographic attributes, knowledge about credit cards and perceived lifestyle outcomes on credit card usage.

International Journal of Consumer Studies, 36 (1), 80-89. doi: 10.1111/j.1470-

6431.2010.00993.x 